\title{
The Effect of Changes in Economic Growth on Non-Performing Loans (NPLs) Problem in the Greek Banking System
}

\author{
Turan Şan ${ }^{1 *} \quad$ Prof.Dr. Sulo Haderi ${ }^{2}$ \\ 1. The Institute of European Studies- University of Tirana-Albania \\ 2.Universiteti Mesdhetar i Shqipërisë-Tirana-Albania
}

\begin{abstract}
The Greek economy was affected very badly by the global economic and financial crisis of 2007-2008. The main reason of this catastrophic event is that the country's speedy economic and financial growth in the pre-crisis period heavily based on the foreign funds, and the flow of these funds stopped immediately -even turned to opposite direction- with the spread of the crisis to Europe. This negative happening as well as the rearrangement of the public debts and remarkable reduction in the bank deposits led to a big financial crisis, and thus economic recession. Meanwhile, the loan quality in the banking system worsened extremely -almost half of the credits turned to bad loan- due to the macroeconomic deterioration as well as the banks' very tolerated lending policies before the crisis, the borrowers' imperfect attitudes, and improper governance. The improvement in NPLs ratio, which started simultaneously with the modest economic recovery in 2017, decreased it to 30.2 percent in 2020 from its peak level of 48.5 percent in 2016. However, a big part of it has been achieved thanks to write-offs and loan-sales.In this study, it was aimed to measure the effect of the changes in economic growth on these drastic changes in NPLs ratio. Although the changes in the gross domestic product (GDP) and NPLs ratio have always been in consistency with the economic theory, except the pandemic year of 2020, the often big differences between their changing rates imply that some other factors have also played significant role on NPLs movements. The findings of some studies for Greece indicate to remarkable impact of both economic growth and the other factors on bad loans issue. The results of our regression analysis also show that the relation between economic growth and NPLs is not so strong.In spite of the noticeable improvement, NPLs ratio is still at a very high level and requires constant remarkable declines in order to come down to the generally accepted levels. To perform this and have economic and financial recovery at the same time, the recovery should not be achieved only by write-offs and portfolio sales, but by collections from borrowers, and executions. The banks and the government should make the necessary changes in their policies and applications so as to decrease NPLs ratio through new lending, compromise with proper borrowers, and court executions.
\end{abstract}

Keywords: Greece, global crisis, sovereign debt crisis, economic growth, non-performing loans.

DOI: $10.7176 /$ RJFA/12-12-05

Publication date:June $30^{\text {th }} 2021$

\section{Introduction}

Although the global financial crisis started to affect Europe, including Greece, in the second part of 2008, the country lived the more severe effects by the sovereign debt crisis -like some other countries in the World- in late 2009 and early 2010, which affected very badly the entire economy, including the banking sector, in the following years. In the pre-crisis period, the foreign investors transferred a large amount of funds to Greece. They felt more confidence to it in the second part of 1990s by the expectation of its entrance in euro zone in 2001 and its realization on time. They thought that European Union (EU) would bring discipline to the country's financial system. Gourinchas, Philippon \& Vayanos (2016) expresses that Greece entered the global crisis with having very high levels of government, private and external debts. The government's debt and net foreign assets were 103.1 percent and 99.9 percent of the output respectively in 2007, which were higher than the figures of Ireland, Italy, Portugal, and Spain, the other worst affected major economies of euro zone. Quite a big part of the government debt, 78.4 percent, was held by the foreign investors. Meantime, the private sector's external financing stood at 92.4 percent of the output. The levels of debts in Greece were more than twice the average of the emerging countries. When it comes to the bank credits, the country had a boom period, which started in the middle of 1990's and lasted in 2008. In this constant economic growth period, the credits to GDP ratio increased from 34.1 percent in 1998 to 103 percent in 2008. In addition to the domestic resources, the banks also got lots of funds from abroad as it was easy to access the international financial markets thanks to the optimistic environment for Greece as explained above. The ratio of the banks' external debts to GDP increased from 12.3 percent in 1999 to 46.2 percent in 2008. With the outbreak of the crisis, those investors largely stopped renewing the matured financing contracts by the thought that the country's sovereign debt could not be maintained as the conditions in the international financial markets changed completely in a negative way. Under these very difficult conditions, the government could not find a remedy, but restructured the public debts with the bailout agreement signed in May 2010 by the financial support of the European institutions and the International Monetary Fund in the amount of 110 billion Euros. This loan did not become sufficient to solve the huge debt crisis, and thus Greece forced its private creditors to sign an agreement 
of reducing its debt from 199.2 billion Euros to 92.1 billion Euros in March 2012 as the first and only country in euro zone acted like this. Meantime, deposit holders made enormous withdrawals from their accounts in the banks because of the panic situation in the society. The amount of retail deposits decreased with 50 percent in the period of 2009-2015. The big decline in the capital and money flows from abroad, the government's new debt repayment plan-reduction in the amounts and extension in the maturities- and the saving holders' decision to take their money out of the market created a big liquidity problem. Meanwhile, European Central Bank (ECB) supported the banking system with its loans, which reached a record level of 158 billion Euros in February 2012.

This big trouble on financial side normally affected the economic growth and employment negatively. More concretely, in the period of 2009-2015, the local economy contracted by 26.4 percent whiles the unemployment rate increased by more than 17 percent. Therefore, business enterprises and households had drastic decreases in their incomes, which led to the continual upward movements in bad loans with considerable amounts. NPLs ratio increased from 5.7 percent as at end-2008 to 48.2 percent as at end-2015. This enormous rise in NPLs and the problems regarding the government bonds' repayments reduced the capital of the banks. These unprecedented negative happenings caused the form of financial crisis to change for the banking sector, from liquidity problem to insolvency case. In other words, the banks had big deteriorations in their financial situations. So, some banks were solved. The deposits in those banks and some of their credits were transferred to the four systemic banks, namely Alpha Bank, Eurobank, National Bank of Greece, and Piraeus Bank. To mitigate the negative effects of these extraordinary economic and financial events, the banking system was recapitalized three times in the three consecutive years, 42 billion Euros in 2013, 8.3 billion Euros in 2014, and 13.7 billion Euros in 2015, by the public funds and private investors' contributions (Gourinchas, Philippon \& Vayanos, 2016).

In the year 2016, the financial situation of the country started to change in positive way. The amount of deposits in the banks has been increasing since May 2016. Besides that the banks have improved considerably their access to the interbank market and have increased their funding from other sources, like issuance of debt securities, loan-sales and securitization. These favorable financial developments enabled the economic growth to be in a positive figure in 2017 -as a first time since 2009- which continued till 2020, the outbreak year of Covid19 Pandemic in Europe. Meanwhile, NPLs ratio also started to go down in 2017- after seeing its year-end peak level of 48.5 percent in 2016- and maintained this positive trend even in the pandemic year, falling to 30.2 percent. However, a big part of the decrease in bad loans has been achieved by write-off ${ }^{1}$ transactions and loan-sales, which are primarily through securitizations, not by collections from borrowers and court executions (Bank of Greece, Financial Stability Reviews, 2016-2020).

The factors of NPLs are generally separated into four groups, namely macroeconomic, bank-specific borrower-related, and the others. In this study, the relation between NPLs ratio and GDP growth rate is analyzed. The graph below shows the year-end NPLs ratios and the yearly GDP growth rates in the period of 2007-2020 (graph: 1)

Graph: 1 NPLs Ratio and GDP Growth Rate Movements (in Percentage)

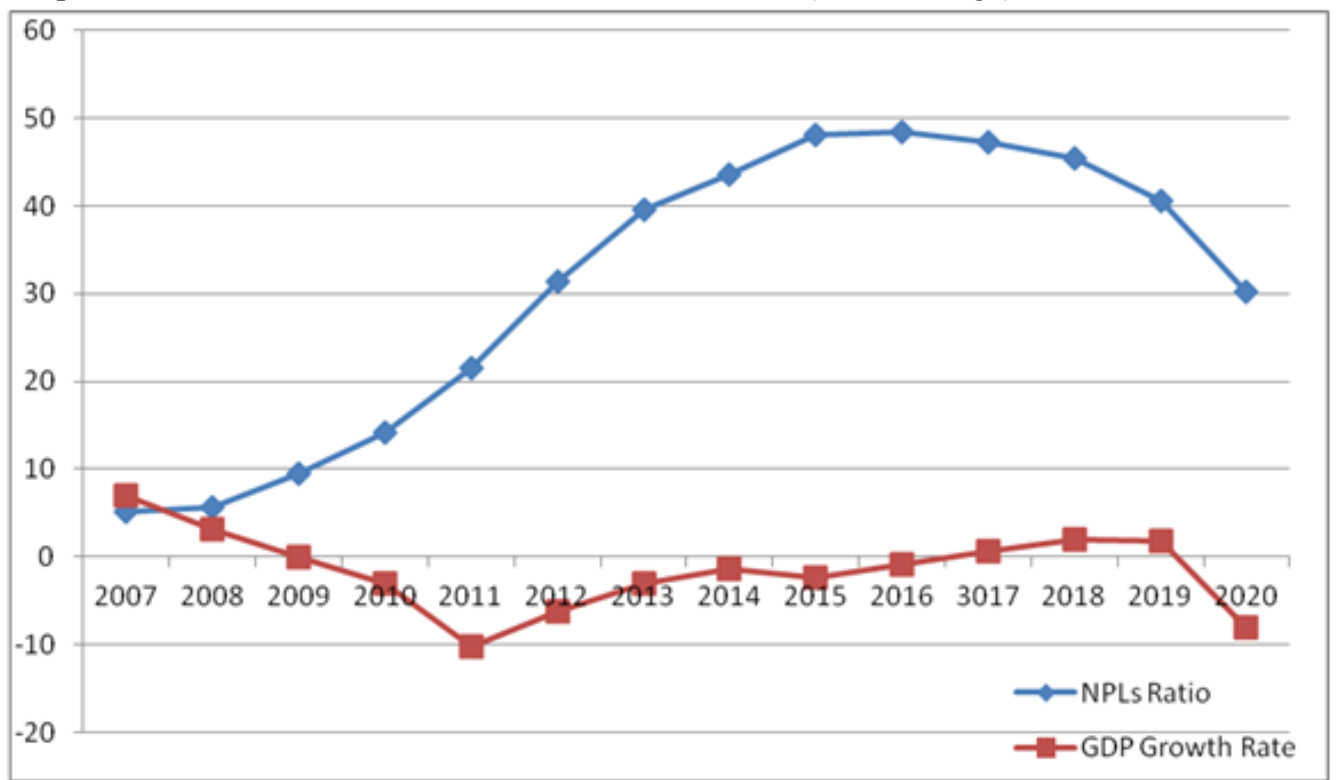

Source: Bank of Greece \& Hellenic Statistical Authority

When it is looked at the above graph, it is seen that the slowdown in economy, which started with the spread

\footnotetext{
${ }^{1}$ It is a method of taking a bad loan out of the bank's balance sheet in compliance with the rules determined by the state authorities.
} 
of the financial crisis in Europe in 2008, turned into a continual contraction by the effect of the sovereign debt problem in 2009. This economic shrinkage - with huge rates in 2001 and 2012- lasted till 2017. The subsequent modest growth period unfortunately continued for a short period due to outbreak of Covid-19 Pandemic, which caused a remarkable negative economic growth of -8.1 percent in 2020 . On the other hand, although the start and acceleration of NPLs rise are identical with that of GDP decline, its following movements are different, on the increase with huge rates till 2016, and on the decrease since 2017 with having the biggest one in 2020.

This big financial crisis and the following considerable worsening in the economic activities certainly played an important role in the rise of bad loans rate, but having an unprecedented level of NPLs ratio, almost half of the loans entered into NPLs category, implies to the remarkable impact of the other factors, such as bank-specific, borrower-related, and the other conditions of the country on this catastrophic financial event.

In the cases where the general economic situation worsens, one of the borrower related factors come forward remarkably. It is the negative change in some people's debt repayment behavior. In other words, those people would like to benefit from this situation by not paying their debts, including bank credits.

Asimakopoulos, Avramidis, Malliaropulos \& Travlos (2016) states that "Despite contributing significantly to the creation of NPLs, financial distress due to the adverse economic conditions is not the sole cause of non-performing loans. Some borrowers may find it economically more attractive not to pay off their liabilities or renegotiate the loan on better terms, in order to use the cash saved for other consumption or saving activity. This decision in credit markets is known as strategic default, a term that has been widely used following the global financial turmoil in 2007.......The Greek crisis offers a unique field for empirical observation of strategic default for two reasons. First, the growth of non-performing loans is so large that it should be possible to empirically observe a sufficiently large sample of strategic defaulters, allowing for more reliable statistical inference. Second, the institutional environment in Greece, mainly related to inadequate information sharing and cooperation between financial institutions, exacerbates the information asymmetry between lenders and borrowers which in turn increases strategic default” (p.4).

The relation between economic growth and NPLs ratio during the economic recovery has been similar to that in the contraction period. On the other hand, it became in contradiction with the economic theory in the pandemic year. The remarkable decline of NPLs ratio in the period where the economy grew with modest rates for three year and then contracted drastically indicates to significant effect of the other factors, write-offs and loan sales, on bad loans recovery.

\section{Literature Review}

The studies show that the trend of macroeconomic situation, which mostly depends on the economic growth rate, has usually been one of the main determinants of the changes in loans quality. It has also been proved that the negative effect of economic slowdown on NPLs ratio is usually in inverse relation with the economic and social development level in a country as well as with the advancement of governance (in public and private sector) and of legal system.

\subsection{The Studies for Greece}

Louzis,, Vouldis \& Metaxas (2012) made a study to identify the determinants of NPLs for business, mortgage, and consumer credits separately. According to the findings, the effect of macroeconomic variables, namely GDP, unemployment, inflation, and interest rates, and management quality on NPLs are significant, but their impact are different on each credit category. Mortgage loans is the least affected one by the macroeconomic conditions. Another study, Monokroussos, Thomakos \& Alexopoulos (2016) examined the trend of bad loans in the period of 2005.2015. Both macroeconomic and bank-specific variables were used in the analysis. The results show that the main reason of the huge rise in NPLs ratio is the contraction in the economic activities and increase in unemployment. There is no any empirical evidence indicating to excessive lending, and financing low quality clients in the pre-crisis period. Asimakopoulos et al. (2016) is a different approach to NPLs issue. They tried to identify the effects of moral hazard and strategic default on the creation of bad loans by using the corporate loans data of 13.070 companies, which belongs to 2005-2015 period. According to the results, one sixth of the firms with problematic loan are strategic defaulters, who do not pay their credits by benefiting from the worsening of the macroeconomic situation. It was also determined that strategic default is in a positive relation with credit outstanding and economic uncertainty while having a negative relation with collateral's value. The other findings are: 1-Medium-sized firms with some business experience compose a big part of the strategic defaulters. 2- There is an inverse relation between activity's profitability and being a strategic defaulter, but defaulters with good profit usually become strategic defaulter. 3- As the crisis becomes deeper, the share of strategic defaulters in total goes down. 4- To give credit to a listed business enterprise does not decrease the risk of having a strategic defaulter. Giannopoulos (2018) aimed to determine the effect of some variables on NPLs during the global crisis period by using a binomial logistic regression. He used the data of $2.591 \mathrm{micro} / \mathrm{small}$ enterprise loans given by one of the four systemic banks in 2005. It was found that the borrowers who have/had problems in relations with the 
government and/or the other business partners usually created trouble for banks in collecting the given loans too. NPLs is in positive relation with the degree of the crisis, and the borrower's age while it is in negative relation with getting collateral (especially strong one), as well as financing clients who operate in their facilities, are residence, and have longer business experience. It is also stated that the effect of these variables decreases as the crisis deepens. Anastasiou, Bragoudakis \& Malandrakis (2019) proposed to identify the determinants of NPLs by testing the effects of both governance and macroeconomic factors. They used the data for the period of 1996-2016. They found that the governance indicators, such as content and application of regulations, government's effectiveness, and political stability, are one of the important determinants of bad loans. NPLs' relation with the systemic liquidity risk in the sector was found as significantly negative. The impact of unemployment, return on assets, and crisis dummy factors are significant with the coefficient of the latter one. On the other hand, the effect of GDP growth, deposits, and bank concentration are not significant.

\subsection{The Studies for the Other Countries}

Anastasiou, Louri \& Tsionas (2016) tested to find the differences -if there is any- between the core and periphery countries of euro zone regarding NPLs issue. The data for the period of 2003Q1-2013Q3 were gathered from 138 banks in the core region, and 88 banks in the periphery. It was determined that bad loans stock rose in the whole zone -more in the periphery countries- starting 2008. It is mostly because of the deterioration in macroeconomic indicators such as unemployment, economic growth, and taxes. Meanwhile, fiscal consolidation, and interest rate margins are significant for the periphery, and credit stock to GDP is significant for the core. Mileris (2014) analyzed the effect of some macroeconomic variables on bad loans in EU countries -with special emphasis on Lithuania- in the period of 2009-2011. According to the results, their effects became bigger in the countries with imperfect economies. Roman (2015), another study for EU countries by using the data for 2000-2013 period, determined that the rise in NPLs ratio occurred at higher levels in the countries which had credit boom in the precrisis period, debt to GDP ratio bigger than 97 percent, as well as drastic GDP decline and unemployment rise with the outbreak of the financial and economic crisis. Beck, Jakubik \& Piloiu (2013) examined the empirical determinants of NPLs in 75 countries over the last decade. The ratio of bad loans was stable in most countries till the financial crisis started to affect their economies in 2007-2008. Although economic slowdown caused a decrease in banks' asset quality in general, its degree in the countries shows big differences, depending on the effects of country-specific variables.

Some studies, for instance, $\operatorname{Nkusu}(2011)$, Klein(2013), Curak(2013), indicate to existence of interaction between economic worsening and bad loan creation. In other words, a rise in problem loans due to deterioration in economic situation makes the crisis deeper. Nkusu (2011) states that a huge rise in NPLs level feeds on itself and its effects last increasingly in the next four years.

\section{Data and Methodology}

In this study, it was aimed to determine the effect of economic growth on the huge rise of NPLs ratio during the global financial and economic crisis and on the following considerable decline in it. Secondary data was used for the analyzed period of 2008Q4-2020Q4. The reason of choosing 2008Q4 as the starting point is that the global crisis showed its first effect on Greece economy in this quarter. GDP growth rate was used as the independent variable, and NPLs ratio as the dependent variable. NPLs ratios were taken from the statistics on Bank of Greece's webpage and GDP growth rates were obtained from Hellenic Statistical Authority's webpage. The quarterly changes in the variables, that is, 49 observations, were tested by using ARMA Maximum Likelihood (NewtonRaphson) regression method. The determination of the changes in GDP growth rate was done by comparing the same quarter of the related years so as avoid the misleading effects of the seasonal movements in economic growth. So, the model used is as shown below:

Where,

$$
N P L=\alpha+\beta_{1} R G D P+e
$$

$N P L$ shows the ratio of non - performing loans to total loans.

$\alpha$ is the intercept which shows NPLs level when the independent variable is equal to 0 .

$\beta_{1}$ Shows the expected slope of NPLs when GDP growth rate changes with $1 \%$.

$R G D P$ is the change in GDP growth rate in percentage.

$e$ represents the standard error. 


\section{The Results}

The results of the regression analysis are as shown below.

Dependent Variable: CHANGE IN NPLS RATIO

Method: ARMA Maximum Likelihood (Newton-Raphson)

Date: 05/16/21 Time: 20:46

Sample: 2008Q4- 2020Q4

Included observations: 49

Convergence achieved after 6 iterations

Coefficient covariance computed using outer product of gradients

\begin{tabular}{|c|c|c|c|c|}
\hline Variable & Coefficient & Std. Error & t-Statistic & Prob. \\
\hline $\mathrm{C}$ & -0.918258 & 2.349480 & -0.390834 & 0.6978 \\
\hline GDP_GROWTH_RATE & -0.449329 & 0.264101 & -1.701353 & 0.0959 \\
\hline$-\operatorname{AR}(1)^{-}$ & 0.405025 & 0.199165 & 2.033615 & 0.0480 \\
\hline $\operatorname{AR}(2)$ & 0.516354 & 0.203189 & 2.541253 & 0.0146 \\
\hline SIGMASQ & 1.140333 & 0.241289 & 4.725997 & 0.0000 \\
\hline R-squared & 0.571133 & Mean dependent var & & 0.506122 \\
\hline Adjusted R-squared & 0.532145 & S.D. dependent var & & 1.647524 \\
\hline S.E. of regression & 1.126906 & Akaike info criterion & & 3.210596 \\
\hline Sum squared resid & 55.87632 & Schwarz criterion & & 3.403639 \\
\hline Log likelihood & -73.65960 & Hannan-Quinn criter. & & 3.283836 \\
\hline F-statistic & 14.64897 & Durbin-Watson stat & & 1.863865 \\
\hline Prob(F-statistic) & 0.000000 & & & \\
\hline
\end{tabular}

Inverted AR Roots

.95

$-.54$

The relation between GDP growth and NPLs is not significant at 0.05 significance level, but at 0.1 level, pointing out that the correlation between them is not so strong. The correlation coefficient is -0.44 , showing that 1 percent change in GDP growth rate leads to an opposite direction movement of 0.44 percent in NPLs ratio. Rsquared value of 0.57 means that 57 percent of the data is explained by the model.

The empirical findings explained above are in consistency both with the figures of economic growth and bad loans, and the findings of some academic studies. The deterioration in the general economic situation certainly played an important role in the creation of such a catastrophic NPLs problem. However, the very huge rise in bad loans ratio -approached 50 percent of total loans- and being still at a very high level after many years from the outbreak of the crisis cannot be explained only by the contraction in the economy, which happened in many European countries somewhat. The influence of the other factors, such as the country's heavy indebtedness, banks' lending policies and applications, borrowers' management styles and behaviors, as well as the governance and legal systems in force, has been at remarkable levels too. Likewise, the following remarkable decline in NPLs ratio, which started together with a modest economic growth and continued even in the pandemic year, point out to the significant impact of write-offs, and loan-sales on it.

\section{NPLs Resolution}

Greece signed three adjustment programs with EU and the international financial institutions as well as one major debt restructuring with its private creditors. Meantime, three rounds of bank recapitalization were performed. All these were done to mitigate the economic and financial crisis where NPLs issue is a main part of the problem. Although a remarkable improvement in bad loans ratio has been achieved, from 48.5 percent in 2016 to 30.2 percent in 2020, it is still at a very high level. This catastrophic situation of the loans quality, in addition to its negative effects on the banks' liquidity, capital adequacy, and profitability, leads to less new lending, and impairment in the market functions, which affect the entire economy negatively. It is also necessary not to forget that a big part of the recovery in bad loans has been achieved not by collections from borrowers and court executions, but by write-offs and credit- sales, which are primarily through securitizations. Write-off is just taking a bad loan out of the bank's balance sheet and continuing to follow it in the newly recorded place till it is collected somehow. In contrast to write-off, portfolio-sales make positive effect in the bank's liquid assets. However, it is not as good as collection from borrower/execution as the banks usually have to accept considerable discounts in selling bad loans, which means losing a remarkable part of the prospective incomes. Meanwhile, some positive changes are happening in the country in the recent years. The deposits in the banks have been on the increase for several years, and the Greek banks have improved considerably their access to the interbank market as well as have increased their funding from other sources (issuance of debt securities, loan-sales and securitization). These 
events are the signs of confidence in the stability of the financial system.

The struggles to resolve NPLs problem have been continuing under the supervision of ECB and the European Commission (EC) as well as their technical and financial supports together with that of the other international institutions. A financial assistance program was signed with the European Stability Mechanism -a part of the ECin August 2015 to determine a comprehensive strategy for the financial system, including legislative reforms. In the same year, European Bank for Reconstruction and Development became shareholder in the four systemic banks with the purpose of making co-investments with them to help NPLs resolution. Meanwhile, the banks are obliged to lower NPLs ratio by 15 percent on a yearly basis according to the regulation mandated by Single Supervisory Mechanism of ECB. Hercules Asset Protection Scheme, shortly called Hercules, is also one of main projects in this fight. It was put in place in late 2019 by the approval of the EC. The four systemic banks, which keep 95 percent of the assets in the banking sector, have joined this plan under the supervision of ECB. It aims to securitize NPLs, and take them out of the banks' balance sheets. It is a good plan as the securitized debts will be sold to diversified investors, who like different investment risk categories, and therefore will not bring any burden to the taxpayers and the government. To have remarkable decreases in the coming years, as it happened in 2020, there is need for more aggressive approaches, like bulk transfer of bad loans, which requires of being not afraid of loss recognition.

In addition to the projects, which are applied by help of the international organizations, the banks and the government should do better in using the classical and well-known ways. The banks currently have sufficient funds thanks to the improvements in the financial stability. They should have more desire to finance the private sector while paying the maximum attention to the risk factors in this pandemic period. They should also do their best to increase the number of cases solved by out-of-court ways. Using these methods more intensively and effectively will not only enable the banks to maintain their activities soundly, but will contribute to the economic growth, and thus lead to decrease in the bad loans ratio through the rise both in the credit stock amount and repayments by borrowers, the ideal way of solving the problem. At the same time, the government should continue to improve the judicial system to get more satisfactory court decisions in a shorter period of time. The achievement in this subject is crucial not only for the banking system's soundness, but for the recovery of the whole economy.

\section{Conclusion}

Greece has been one of the worst affected countries by the last global crisis as it lived not only an economic recession, but a catastrophic sovereign debt crisis too. Starting the second part of 1990's, the country had plenty of fund inflows from abroad thanks to expectation of its entrance in euro zone and its realization on time. The economy, including the banking sector, grew constantly with considerable rates by abundance of the available funds. When the crisis started to effect Europe, the foreign investors stopped lending to Greece and moreover asked for return of the previously given financial resources. In addition to that, the government restructured its debts, and the deposit holders made enormous withdrawals from their bank accounts. These unexpected events created a huge general liquidity problem, which caused drastic falls in economic growth, and thus remarkable declines in incomes of business enterprises and households. Under these difficult economic and financial conditions, NPLs ratio increased enormously, mainly due to the borrowers' inabilities to repay their credits, but also by the other factors, such as the banks' extremely flexible lending conditions in the pre-crisis period, borrowers' improper behaviors -including abuse of the general economic situation- and some mistakes in the government policies and applications.

In this study, the relation between GDP growth and NPLs ratio was analyzed to identify the effect of the former on the latter. When it is looked at their movements during the crisis and afterward, it is seen that in the years where the economy contracted, NPLs ratio had been in constant rise with remarkable rates, regardless of the changes in GDP growth rate. In the economic recovery years with modest growth rates, NPLs ratio went down somewhat, but the considerable decrease occurred in the pandemic year of 2020. However, these declines have been achieved mostly by write-offs and loan-sales, instead of collection from clients or by court executions. By the way, many studies indicate to existence of some other factors, except the economic crisis, behind this huge NPLs rise too. The results of the regression analysis also show that the changes in the economic situation cannot explain by itself the catastrophic increase and the following considerable decline in NPLs ratio, but needs the support of the other factors' explanatory power.

All the struggles to recover the general economic situation have also contributed to NPLs resolution somewhat. Besides that some peculiar arrangements for the banking sector, such as capital injection, have played role in the decline of NPLs ratio from 48.5 percent in 2016 to 30.2 percent in 2020 . In spite of all these directly and indirectly supportive arrangements, and of allowing the banks to do balance sheet make- ups by write-offs, and to sell their bad loans with considerable discounts, NPLs ratio is at a very high level, which affects the banking system's soundness, market mechanism, and the overall economy badly.

To bring NPLs ratio to the internationally accepted normal levels, remarkable decreases, like happened in 2020, should be achieved in the following years. The banks and the government should be more active in the 
resolution process instead of letting it to be solved only by the internationally maintained projects. The banks should have more desire to make new credits while trying to increase the number of problematic loans solved through out- of- court ways. Meantime, the legislative reforms should be continued for speediness and effectiveness of the court decisions. In this way, the development of real economy and of the banking system will be possible while having a bigger share solved by the ideal ways -payments by borrowers, and collections by execution- in NPLs decrease. Meanwhile, write-off transactions, and loan-sales, especially in bulk form, should be kept on in order to get rid of this big issue as soon as possible.

\section{References}

Anastasiou,D., Bragoudakis,Z. \& Malandrakis,I. (2019), Non-Performing Loans, Governance Indicators and Systemic Liquidity Risk: Evidence From Greece, Bank of Greece, Working Paper 260.

Anastasiou, D., Louri, H. \& Tsionas, M.G. (2016), Non-Performing Loans in the Euro Area: Are Core-Periphery Banking Markets Fragmented?, Bank of Greece, Working Paper 219.

Asimakopoulos,I., Avramidis,P. K., Malliaropulos,D. \&Travlos,N.G. (2016), Moral Hazard and Strategic Default: Evidence From Greek Corporate Loans, Bank of Greece, Working Paper 211.

Bank of Greece, Financial Stability Reviews, 2016-2020.

Bank of Greece, Statistics, Evolution of Loans and Non-Performing Loans (2002 to Today), NPL Solo.

Beck, R., Jakubik, P., \& Piloiu, A. (2013), Non-Performing Loans: What Matters in Addition to the Economic Cycle?, European Central Bank, Working Paper Series 1515.

Curak, M., Sandra, P., \& Klime, P. (2013), Determinants of Non-Performing Loans - Evidence From Southeastern European Banking Systems, Banks and Bank Systems 8(1), 45-53.

Giannopoulos,V. (2018), What Causes Non-Performing Loans? The Case of Greece Using Primary Accounting Data, Open Journal of Accounting, 07(04), 191-206.

Gourinchas, P.O., Philippon, T. \& Vayanos, D. (2016), The Analytics of the Greek Crisis, The University of Chicago Press Journals, National Bureau of Economic Research, Macroeconomics Annual, Vol.31, 1-81.

Hellenic Statistical Authority, Statistics, Economy, Indices, Quarterly National Accounts, Gross Domestic Product, Non-Seasonally Adjusted Figures.

Klein,N. (2013), Non-Performing Loans in Central, Eastern and South-Eastern Europe-Determinants and Impact on Macroeconomic Performance, International Monetary Fund- 13/72.

Louzis,D.P.,Vouldis,A.T.\&Metaxas,V.L.(2012),Macroeconomic and Bank-Specific Determinants of NonPerforming Loans in Greece: A comparative Study of Mortgage, Business and Consumer Loan Portfolios, Journal of Banking \& Finance, Elsevier,Vol.36, Issue 4, 1012-1027.

Mileris,R.(2014), Macroeconomic Factors of Non-Performing Loans in Commercial Banks, Ekonomika,,Vol.(93)1.

Monokroussos,P.,Thomakos,D.D.\&Alexopoulos,T.A.(2016), Explaining Non-Performing Loans in Greece: A Comparative Study on the Effects of Recession and Banking Practices, GreeSE Paper No.101, Hellenic Observatory Papers on Greece and Southeast Europe.

Nkusu,M.(2011),Non-Performing Loans and Macro-Financial Vulnerabilities in Advanced Economies, IMF Working Paper.

Roman,A.\& Bilan,I. (2015), An Empirical Analysis of the Macroeconomic Determinants of Non-Performing Loans in EU 28 Banking Sector, Revista Economic, Vol.67(2),108-127. 